\title{
The effect of different habitat conditions on temporal and spatial variation in selected population properties of the rare plant species Trollius europaeus L.
}

\author{
Kinga Kostrakiewicz-Gierałt ${ }^{1 *}$, Maciej Kozak ${ }^{1}$ \\ \& Katarzyna Kozłowska-Kozak ${ }^{2}$
}

\author{
${ }^{1}$ Department of Plant Ecology, Institute of Botany, Jagiellonian University, Lubicz 46, 31-512 Kraków, Poland \\ ${ }^{2}$ ul. Koszyka 8/30, 45-720 Opole, Poland \\ * corresponding author (e-mail: kinga.kostrakiewicz@uj.edu.pl)
}

\begin{abstract}
The investigations presented here were carried out in years 2013-14, in a Molinietum caeruleae meadow with interrupted plant cover caused by animal activity (patch I); abandoned Molinietum caeruleae meadows with untouched plant canopy, dominated by species with considerable height of the above-ground parts (patches II-VI); as well as the edge (patch VII) and the interior (patch VIII) of a birch woodlot. The height of standing vegetation and soil moisture increased in subsequent patches, whereas the light availability at ground level showed inverse tendency. The abundance of Trollius europaeus subpopulations in all studied patches was rather low. In patch I, juvenile individuals dominated, while in other stands - flowering adults prevailed. The lack of temporal variability in the number of basal leaves observed in patches III, IV, V, VI and VII might be due to lack of available area necessary for clonal proliferation of ramets, while the increase of basal leaves number in other sites might suggest unlimited iterative growth. The dimensions of basal leaves in consecutive years were constant in majority of subpopulations, while they showed strong spatial variability increasing gradually from patch I to patch VII and, subsequently, decreasing in patch VIII. The substantial dimensions of basal leaves may enable better light capture in sites with great level of lateral shade, while smaller dimensions in patches located within a woodlot may be due to shade from above created by trees. Lack of temporal variability and presence of substantial spatial variability in the number and height of generative stems, as well as flower production might enhance chances for successful pollination in a competitive environment. Significant changes of follicle number in time and space suggest successful process of pollination in all patches excluding patch VIII. The weak condition of the ramet clusters in patch I is not compensated by considerable seedling recruitment, whereas the satisfactory state of the ramet clusters in patches II-VIII may not suffice for the long-term maintenance of populations in colonized areas.
\end{abstract}

Key words: abundance, basal leaf, disturbance follicle, flowering stem, ramet cluster, succession, Molinietum caeruleae

\section{Introduction}

The European globeflower Trollius europaeus L. (Ranunculaceae) is a perennial species that produces several basal leaves with lamina consisting of five deeply-cut lobes. The generative stems bear one or several flowers, pollinated mainly by bumblebee queens or Chiastocheta flies (Pellmyr 1992). Mature multiple follicles (containing numerous follicles) open, releasing numerous passively dispersed seeds that germinate during the following season (Doroszewska 1974; Jaeger \& Després 1998; Piękoś-Mirkowa \& Mirek 2003). T. europaeus individuals belong to the group of clonal plants (Antkowiak 1999, 2002) and reproduce via multi-plication of the above-ground units and enlargement of below-ground organs, followed by disintegration of most senile parts.

T. europaeus L. is distributed over central and northern Europe (Hultén \& Fries 1986). According to Matuszkiewicz (2001), its populations establish across a wide range of habitats: from shady areas of oak woods (Potentillo albae-Quercetum) and tall herb communities (Filipendulo-Geranietum) to moist meadows (CirsioPolygonetum bistortae, Polygono bistortae-Trolietum europaei, Molinietum caeruleae). 
At the same time, it should be added that, despite the species large range and occurrence in various habitats, individual populations are rather small in size. Therefore, $T$. europaeus presents one of the seven patterns of rarity of taxa proposed by Rabinowitz (1981) and Rabinowitz et al. (1986). It is considered one of the most endangered species in all Europe and is included in numerous national Red Data Books and on Red Lists (Curtis \& McGough 1988; Benkert \& Klemm 1993; Ingelög et al. 1993; Moser et al. 2002; Cheffings \& Farrell 2005; Király 2007; Petrova \& Vladimirov 2009). In Poland, T. europaeus is a strictly protected species (Regulation 2014). Although not included on the Red List of plants and fungi of Poland (Zarzycki \& Szelag 2006), it does appear in numerous regional Red Books and on Red Lists (Jakubowska-Gabara \& Kucharski 1999; Bernacki et al. 2000; Nowak 2002; Głowacki et al. 2003; Kącki et al. 2003, Jackowiak et al. 2007; Kopeć \& Michalska-Hejduk 2012).

Heretofore, observations of selected features of T. europaeus populations have been carried out by numerous authors (Antkowiak 1999, 2002; Antkowiak \& Maciejewska 1999; Kochanowska \& Gamrat 2007; Jagodziński et al. 2008; Juśkiewicz-Swaczyna et al. 2008; Kostrakiewicz 2009; Muncaciu et al. 2010). However, despite growing interest in this topic, the present state of knowledge is still unsatisfactory and further investigations are badly needed. In particular, observations carried out on populations inhabiting diverse habitat conditions may expand existing knowledge concerning the status of populations and provide a basis for effective protection programmes. With this in mind, investigations were conducted on selected traits of T. europaeus subpopulations occurring along the successional gradient. The specific aim of these investigations was to assess (1) microenvironmental conditions in the studied patches; (2) temporal and spatial variability of the abundance and structure of subpopulations, the number and size of basal leaves, and the level of generative reproduction.

\section{Material and methods}

\subsection{The study area}

The studies were carried out in Pychowice and Kostrze districts, on the western border of Kraków, south of the Vistula River (southern Poland). The research area is located at ca. $210 \mathrm{~m}$ a.s.1, on a low flood terrace of the Vistula, at heights of 3.0-6.0 m. The water table is $0.2 \mathrm{~m}$ below the surface of the ground. The peaty or clay- and silt-laden soils common in the Vistula valley are covered by Molinietum caeruleae patches (Dubiel 2005). The abandonment of traditional land use over, at least, past dozen years favoured the encroachment of Phragmites australis and Salix spp., leading to fragmentation of meadows (Dubiel 1991, 1996).

\subsection{Patch characteristics}

Altogether, investigations were carried out in eight patches (Fig. 1). Patch I was located in a Molinietum caeruleae community dominated by small meadow taxa with procumbent or erect stems not exceeding $30 \mathrm{~cm}$. Frequently, the above-ground parts of plants had been damaged by farm animals. Patches II-VI were situated in abandoned Molinietum caeruleae meadows with intact standing vegetation. They were characterised by different dominants: patch II was dominated by small meadow taxa; patch III (representing an early stage of succession) - by shrub willows; patch IV (representing a medium stage of succession) - by shrub and tree willows as well as large tussock sedges and grasses; patch V (representing a medium stage of succession) - by shrub willows and deciduous trees; patch VI (representing a late stage of succession) - by large tussock sedges and grasses, common reeds and deciduous trees. Other locations were established at the edge (patch VII) and interior (patch VIII) of a woodlot dominated by birch. The area of each patch was precisely mapped using a Garmin GPSMAP 62s handheld navigator. Habitat conditions were surveyed in all patches on the $21^{\text {st }}$

May 2013, at the midpoint of the flowering of T. europaeus which lasted that year from the first week of May to the third week of June. The height of vascular plants was evaluated on the basis of measurements of 20 randomly chosen stems of different species, performed using a folding tape measure. Light intensity

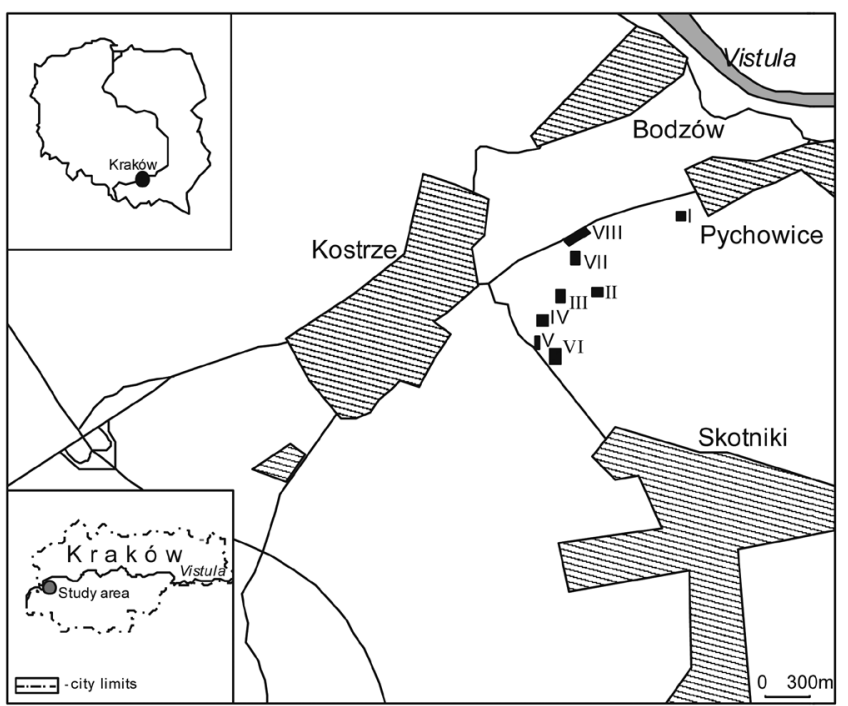

Fig. 1. The locality of studied Trolius europaeus populations Explanations: I - patch of Molinietum caeruleae dominated by small meadow species, frequently disturbed by trampling and burrowing, II-VI - abandoned Molinietum caeruleae meadows in different stages of overgrowing, VII - patch situated at the edge of birch woodlot, VIII - patch situated in the interior of birch woodlot 
Table 1. The characteristics of habitat conditions in the studied patches of Trollius europaeus L. occurring in: Molinietum caeruleae meadow dominated by small meadow species, frequently disturbed by trampling and burrowing (patch I), overgrowing Molinietum caeruleae meadows dominated by species with different height (patches II-VI), edge (patch VII) and interior (patch VIII) of birch woodlot

\begin{tabular}{|c|c|c|c|c|c|c|c|c|}
\hline & \multicolumn{8}{|c|}{ Patches } \\
\hline & I & II & III & IV & V & VI & VII & VIII \\
\hline $\begin{array}{l}\text { The site area } \\
\left(\mathrm{m}^{2}\right)\end{array}$ & 300 & 500 & 1000 & 1200 & 1000 & 1500 & 500 & 1200 \\
\hline $\begin{array}{l}\text { No. of } \\
\text { species in } \\
\text { patch }\end{array}$ & 35 & 43 & 29 & 26 & 21 & 17 & 19 & 18 \\
\hline $\begin{array}{l}\text { Dominant } \\
\text { species } \\
(\text { cover }> \\
20 \%)\end{array}$ & $\begin{array}{l}\text { Lychnis } \\
\text { flos-cuculi, } \\
\text { Lotus } \\
\text { corniculatus }\end{array}$ & $\begin{array}{l}\text { Centaurea } \\
\text { jacea, } \\
\text { Gladiolus } \\
\text { imbricatus, } \\
\text { Sanguisorba } \\
\text { officinalis }\end{array}$ & $\begin{array}{l}\text { Salix } \\
\text { repens ssp. } \\
\text { rosmarinifolia }\end{array}$ & $\begin{array}{l}\text { Salix } \\
\text { repens ssp. } \\
\text { rosmarinifolia } \\
\text { Filipendula } \\
\text { ulmaria }\end{array}$ & $\begin{array}{l}\text { Salix } \\
\text { cinerea, } \\
\text { Populus } \\
\text { tremula }\end{array}$ & $\begin{array}{l}\text { Phragmites } \\
\text { australis, } \\
\text { Molinia } \\
\text { caerulea, } \\
\text { Deschampsia } \\
\text { caespitosa }\end{array}$ & $\begin{array}{l}\text { Betula } \\
\text { pendula, } \\
\text { Populus } \\
\text { tremula, } \\
\text { Salix } \\
\text { cinerea }\end{array}$ & $\begin{array}{l}\text { Betula } \\
\text { pendula, } \\
\text { Acer } \\
\text { platanoides, } \\
\text { Fraximus } \\
\text { excelsior }\end{array}$ \\
\hline $\begin{array}{l}\text { Subdominant } \\
\text { species } \\
\text { (cover } \\
5-20 \%)\end{array}$ & $\begin{array}{l}\text { Lathyrus } \\
\text { pratensis, } \\
\text { Briza media }\end{array}$ & $\begin{array}{l}\text { Polygonum } \\
\text { bistorta, } \\
\text { Iris sibirica }\end{array}$ & $\begin{array}{l}\text { Iris sibirica, } \\
\text { Carex } \\
\text { gracilis, } \\
\text { Betonica } \\
\text { officinalis }\end{array}$ & $\begin{array}{l}\text { Salix cinerea, } \\
\text { Molinia } \\
\text { caerulaea, } \\
\text { Deschampsia } \\
\text { caespitosa }\end{array}$ & $\begin{array}{l}\text { Phragmites } \\
\text { australis }\end{array}$ & $\begin{array}{l}\text { Betula } \\
\text { pendula }\end{array}$ & $\begin{array}{l}\text { Molinia } \\
\text { caerulaea, } \\
\text { Sambucus } \\
\text { nigra, }\end{array}$ & $\begin{array}{l}\text { Sambucus } \\
\text { nigra, } \\
\text { Acer } \\
\text { negundo }\end{array}$ \\
\hline
\end{tabular}

was estimated on the basis of 20 measurements taken randomly at the soil level. Light intensity was examined between the hours of 10.00 a.m. and 12.00 noon with a Roline RO-1332 digital light meter (accuracy $+/-5 \%+$ 10 digits; measuring range 0.01-200,000 lx). Humidity at ground level was evaluated on the basis of 20 measurements taken randomly using a hand-held BIOWIN 071505 soil moisture sensor (measuring range 1-10). Site conditions in individual patches are summarised in Table 1.

\subsection{Population characteristics}

The studies were conducted in 2013-14. The individual and the ramet cluster were adopted as the basic demographic units. An individual (genet) is a plant emerging from a single zygote. The terms 'individual' and 'genet' are used in association with the juvenile stage, since only at this stage can it be established with certainty that it has developed from a zygote. The term 'ramet cluster', understood as an integral group of basal leaves or/and generative stems, is applied to plants representing later developmental stages (vegetative and generative). A ramet cluster may be either a genet or a group of independent units emerging as a result of genet fragmentation. The field studies were conducted between 1 May and 15 October 2013 and 7 May and 25 October 2014. In each patch, all individuals and ramet clusters were inventoried, marked with plastic tags and assigned to one of the following developmental stages according to Ziman (1983): juvenile (individual with two basal leaves), vegetative (ramet cluster with basal leaves only), generative (ramet cluster with at least one generative stem). Subsequently, in each adult ramet cluster, the following traits were counted/measured: (a) the number of basal leaves, (b) the height of the petioles of all basal leaves (from ground level to the beginning of the leaf lamina), (c) the maximal width of the leaf lamina of all basal leaves, (d) the length of the central leaf lobe of all basal leaves, (e) the number of generative stems, (f) the height of all generative stems (from ground level to the perianth segments of the uppermost flower), (g) the number of flowers on each generative stem. Then, the number of follicles was determined in each of 20 randomly chosen multiple follicles. The height of petioles was measured using the folding tape measure, while the dimensions of leaf lamina were measured using a Lux Tools Comfort digital caliper (accuracy $+/-0.01$; measuring range $0.1-150 \mathrm{~mm})$.

\subsection{Statistical analyses}

The chi-square statistic was applied to test whether significant differences existed among sites in terms of the percentage of individuals/ramet clusters representing different developmental stages. Normal distribution of the untransformed data of each studied trait in an individual sample (from particular patch and year) was tested using the Kolmogorov-Smirnov test, while variance homogeneity was tested using the Levene test at the significance level of $p<0.05$. As the values of individual characteristics in some groups were not consistent with normal distribution and the variance was not homogeneous, the non-parametric Kruskal-Wallis test and post-hoc test were used to check the significance 
Table 2. The habitat conditions in the studied patches of Trollius europaeus L. occurring in: Molinietum caeruleae meadow dominated by small meadow species, frequently disturbed by trampling and burrowing (patch I), overgrowing Molinietum caeruleae meadows dominated by species with different height (patches II-VI), edge (patch VII) and interior (patch VIII) of birch woodlot

\begin{tabular}{|c|c|c|c|c|c|c|c|c|c|c|}
\hline & & \multicolumn{8}{|c|}{ Patch } & \multirow{2}{*}{$\begin{array}{c}\text { the Kruskal- } \\
\text { Wallis } \mathrm{H} \text { test } \\
(d f=7, \mathrm{~N}=160), \\
p \text { value }\end{array}$} \\
\hline & & I & II & III & IV & $\mathrm{V}$ & VI & VII & VIII & \\
\hline \multirow{3}{*}{ 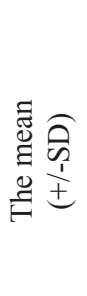 } & $\begin{array}{l}\text { vascular plant } \\
\text { height }[\mathrm{cm}]\end{array}$ & $\begin{array}{l}18.15 \\
(3.7)\end{array}$ & $\begin{array}{l}26.6 \\
(7.2)\end{array}$ & $\begin{array}{c}57.8 \\
(13.5)\end{array}$ & $\begin{array}{l}61.55 \\
(15.0)\end{array}$ & $\begin{array}{l}75.45 \\
(21.6)\end{array}$ & $\begin{array}{l}86.85 \\
(23.8)\end{array}$ & $\begin{array}{l}220.7 \\
(42.8)\end{array}$ & $\begin{array}{c}300.15 \\
(78.6)\end{array}$ & $\begin{array}{l}125.65 \\
p=0.00001\end{array}$ \\
\hline & $\begin{array}{l}\text { soil humidity } \\
\text { (range 1-10) }\end{array}$ & $\begin{array}{c}5.2 \\
(2.8)\end{array}$ & $\begin{array}{l}5.45 \\
(1.8)\end{array}$ & $\begin{array}{l}5.75 \\
(2.5)\end{array}$ & $\begin{array}{c}5.8 \\
(3.1)\end{array}$ & $\begin{array}{l}6.65 \\
(2.7)\end{array}$ & $\begin{array}{c}6.6 \\
(1.9)\end{array}$ & $\begin{array}{l}7.55 \\
(3.0)\end{array}$ & $\begin{array}{c}6.5 \\
(2.4)\end{array}$ & $\begin{array}{l}48.09 \\
p=0.0005\end{array}$ \\
\hline & $\begin{array}{l}\text { light intensity } \\
\text { at soil level } \\
{[1 \mathrm{x}]}\end{array}$ & $\begin{array}{l}101,100 \\
(45,780)\end{array}$ & $\begin{array}{c}95,400 \\
(32,970)\end{array}$ & $\begin{array}{c}78,400 \\
(24,500)\end{array}$ & $\begin{array}{c}78,500 \\
(18,650)\end{array}$ & $\begin{array}{c}59,500 \\
(32,890)\end{array}$ & $\begin{array}{c}54,500 \\
(25,230)\end{array}$ & $\begin{array}{l}29,400 \\
(9,560)\end{array}$ & $\begin{array}{c}5,300 \\
(2,120)\end{array}$ & $\begin{array}{l}83.14 \\
p=0.00003\end{array}$ \\
\hline
\end{tabular}

Explanations: the mean soil humidity, 1-3 (dry), 4-7 (moist), 8-10 (wet)

of differences between patches in microenvironmental conditions (standing vegetation height, soil moisture and light availability) and individual traits (number of basal leaves and generative stems, the height of the petioles of basal leaves, the width and length of the central leaf lobe of basal leaves, the number of flowers in each generative stem and the number of follicles in multifollicles). All statistical analyses were performed using STATISTICA 10 software.

\section{Results}

\subsection{Habitat conditions in studied patches}

The height of standing vegetation increased significantly $(\mathrm{H}=125.65, p=0.00001)$ from patches I to VIII. The soil moisture increased remarkably from patches I to VII, while in patch VIII, the ground humidity diminished moderately $(\mathrm{H}=48.09, p=0.0005)$. The light availability at ground level decreased substantially $(\mathrm{H}=83.14, p=0.00003)$ across consecutive sites (Table 2).

\subsection{Temporal and spatial variability of abundance} and developmental structure of subpopulations

The number of ramet clusters and individuals per patch and per $1 \mathrm{~m}^{2}$ showed temporal variability only in patch I. Throughout the study period, the greatest values of abundance were presented by the subpopulation located in patch I, while in other patches they were much lower (Table 3). The structure of developmental stages did not show temporal variability in all subpopulations (Fig. 2). In two consecutive, years in patch I, juveniles dominated, while in other stands - flowering adults prevailed $\left(\chi_{2013}^{2}=508.8, d f=12, p<0.001 ; \chi_{2014}^{2}=458.2\right.$, $d f=14, p<0.001)$.

\subsection{Temporal and spatial variability of number and dimensions of basal leaves}

The number of basal leaves did not show temporal variability in patches III, IV, V, VI and VII (U=20.5$120.0, p=0.08-0.5)$, but increased significantly in 2014 in patches I, II, and VIII ( $\mathrm{U}=0.5-23.0, p=0.03-0.0001)$ (Table 4). The height of petioles did not show temporal variability in all patches $(\mathrm{U}=-1.22-2.27, p=0.06-0.78)$.

Table 3. The number of ramet clusters and individuals of Trollius europaeus in the patches occurring in: Molinietum caeruleae meadow dominated by small meadow species, frequently disturbed by trampling and burrowing (patch I), abandoned Molinietum caeruleae meadows in different stages of overgrowing (patches II-VI), and on the edge (patch VII) and in the interior (patch VIII) of birch woodlot

\begin{tabular}{lccccccccc}
\hline & \multicolumn{10}{c}{ Patch } \\
\cline { 2 - 10 } & & I & II & III & IV & V & VI & VII & VIII \\
\hline No. of ramet clusters & 2013 & 23 & 6 & 9 & 12 & 18 & 20 & 11 & 17 \\
and individuals per patch & 2014 & 21 & 6 & 9 & 12 & 18 & 20 & 11 & 17 \\
No. of ramet clusters & 2013 & 0.08 & 0.01 & 0.009 & 0.01 & 0.02 & 0.01 & 0.02 & 0.01 \\
and individuals per 1 $\mathrm{m}^{2}$ & 2014 & 0.07 & 0.01 & 0.009 & 0.01 & 0.02 & 0.01 & 0.02 & 0.01 \\
\hline
\end{tabular}




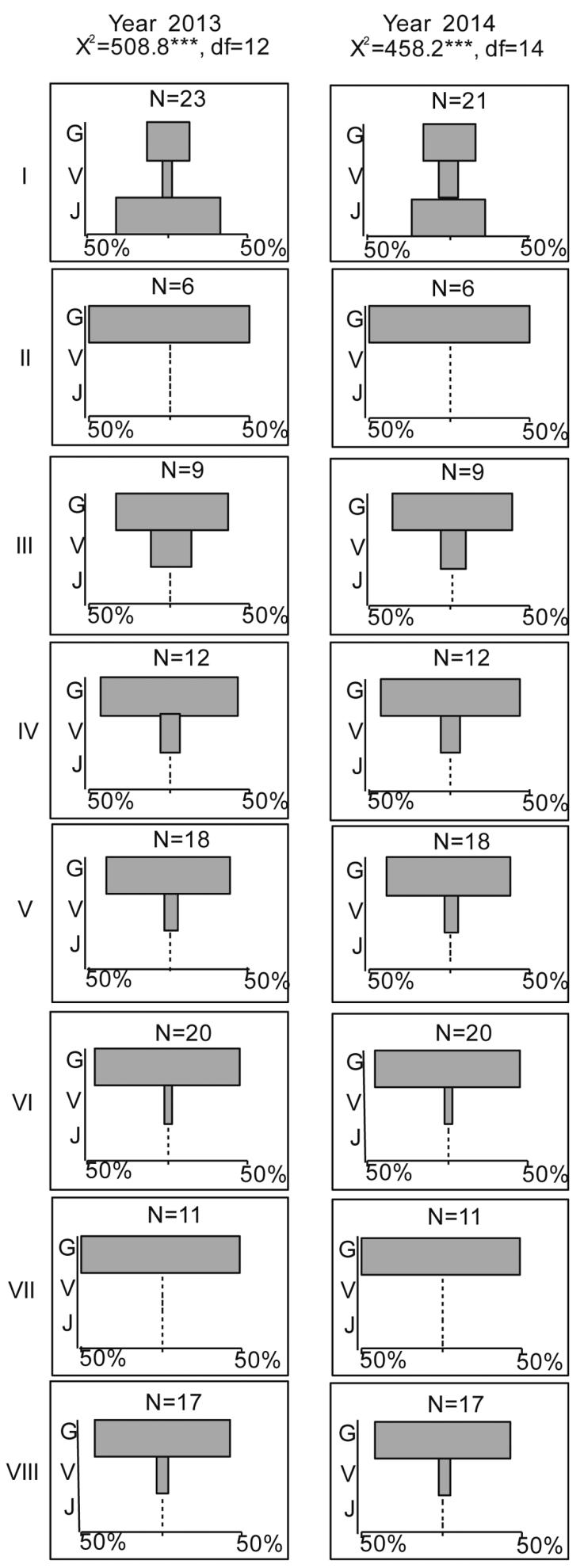

Fig. 2. The of developmental stages of studied populations of Trollius europaeus L. occuring in: Molinietum caeruleae meadow dominated by small meadow species, frequently disturbed by trampling and burrowing (I), abandoned Molinietum caeruleae meadows in different stages of overgrowing (II-VI), and at the edge (VII) and in the interior (VIII) of birch woodlot in the years 2013-2014

Explanations: the $\mathrm{Y}$ axis depicts developmental stages: $\mathrm{J}$ - juvenile, $\mathrm{V}-$ vegetative and $\mathrm{G}$-generative; the $\mathrm{X}$ axis depicts the percentage of ramet clusters in individual stages

The width of lamina of basal leaves in consecutive seasons was similar in patches I, II, IV, V and VI
$(\mathrm{U}=-1.89-1.69, p=0.06-0.23)$, whereas it decreased remarkably in patches III, VII and VIII $\left(\mathrm{U}_{\mathrm{III}}=4.11\right.$, $\left.p=0.0004 ; \mathrm{U}_{\mathrm{VII}}=2.03, p=0.04, \mathrm{U}_{\mathrm{VII}}=-2.05, p=0.04\right)$. The length of the central leaf lobe of basal leaves was constant during the entire study period in patches II, III, IV, VI, VII and VIII (U=-2.09-1.43, $p=0.06-0.96)$, while it significantly decreased in 2014 in patches I and $\mathrm{V}\left(\mathrm{U}_{\mathrm{I}}=4.0, p=0.0004 ; \mathrm{U}_{\mathrm{V}}=4.84, p=0.00001\right)$.

During the two-year period, the number of basal leaves was much greater in patches I, II, III and IV than in patches V, VI, VII and VIII $\left(\mathrm{H}_{2013}=66.01\right.$, $\left.p=0.0005 ; \mathrm{H}_{2014}=58.19, p=0.00006\right)$. Strong spatial variability over the entire study period was shown by the height of the petioles of basal leaves $\left(\mathrm{H}_{2013}=498.63\right.$, $p=0.00 ; \mathrm{H}_{2014}=740.61, p=0.00$ ), the width of leaf lamina $\left(\mathrm{H}_{2013}=383.22, p=0.00 ; \mathrm{H}_{2014}=419.08, p=0.00\right)$, and the length of the central lobe $\left(\mathrm{H}_{2013}=227.81, p=0.00\right.$; $\mathrm{H}_{2014}=297.46, p=0.00$ ). These values increased gradually from patch I to patch VII and then decreased slightly in patch VIII (Fig. 3).

3.4. Temporal and spatial variability in the number of generative stems, as well as flower and fruit production

The number of generative stems in subsequent seasons did not show temporal variability $(\mathrm{U}=10.5-163.0$, $p=0.26-0.91$ ) (Table 5). The similar height of generative stems among consecutive years was found in patches I, IV, V and VII ( $\mathrm{U}=-1.62$ to $1.79, p=0.07-0.31)$. In 2014, a significant decrease in the height of generative stems was observed in patch VIII $(\mathrm{U}=3.78, p=0.0001)$, while a remarkable increase was found in patches II, III and VI $(\mathrm{U}=-5.38$ to $-3.11, p=0.0003-0.001)$. The number of flowers per generative stem did not show temporal variability ( $\mathrm{U}=-1.69-0.38, p=0.09-0.95)$. No difference in the number of follicles per multiple follicle among consecutive seasons was observed in patches IV and $\mathrm{V}$ $\left(\mathrm{U}_{\mathrm{IV}}=-1.37, p=0.16 ; \mathrm{U}_{\mathrm{V}}=-0.43, p=0.66\right)$. A significant increase in the above-mentioned trait in 2014 was found in patches I, II, III, VI, and VII ( $\mathrm{U}=-3.38$ to -0.43 , $p=0.0007-0.03$ ), while a decrease was recorded in patch VIII $(\mathrm{U}=2.12, p=0.03)$.

Over the entire study period, the number of generative stems per ramet cluster showed moderate spatial variability which was much greater in patch II than in other patches $\left(\mathrm{U}_{2013}=29.40, p=0.0004 ; \mathrm{U}_{2014}=24.40\right.$, $p=0.0004$ ) (Fig. 4). The mean height of generative stems increased remarkably from patch I to patch VIII $\left(\mathrm{U}_{2013}=195.16, p=0.00 ; \mathrm{U}_{2014}=185.30, p=0.000\right)$. Also, the number of flowers per generative stem increased gradually over successive study sites $\left(\mathrm{U}_{2013}=54.49\right.$, $\left.p=0.00 ; \mathrm{U}_{2014}=26.95, p=0.0004\right)$. The number of follicles in multiple follicles increased from patch I to VII, while in patch VIII it declined moderately $\left(\mathrm{U}_{2013}=59.44\right.$, $p=0.000 ; \mathrm{U}_{2014}=40.25, p=0.000$ ). 
Table 4. The temporal variability of number and height, lamina width and length of central lamina lobe of basal leaves in populations of Trollius europaeus L. occurring in: Molinietum caeruleae meadow dominated by small meadow species, frequently disturbed by trampling and burrowing (patch I), abandoned Molinietum caeruleae meadows in different stages of overgrowing (patches II-VI), and on the edge (patch VII) and in the interior (patch VIII) of birch woodlot in the years 2013-2014

\begin{tabular}{|c|c|c|c|c|c|c|c|c|c|c|c|c|}
\hline \multirow[t]{2}{*}{ Patch } & \multicolumn{2}{|c|}{$\begin{array}{c}\text { The mean } \\
\text { number (+/-SD) } \\
\text { of basal leaves }\end{array}$} & \multirow[t]{2}{*}{$\begin{array}{l}\text { U Mann- } \\
\text { Whitney } \\
\text { test; } p\end{array}$} & \multicolumn{2}{|c|}{$\begin{array}{c}\text { The mean } \\
\text { height (+/-SD) } \\
\text { of basal leaves }\end{array}$} & \multirow[t]{2}{*}{$\begin{array}{c}\mathrm{U} \\
\text { Mann- } \\
\text { Whitney } \\
\text { test; } p\end{array}$} & \multicolumn{2}{|c|}{$\begin{array}{l}\text { The mean width } \\
(+/-S D) \text { of } \\
\text { lamina of basal } \\
\text { leaves }\end{array}$} & \multirow[t]{2}{*}{$\begin{array}{l}\text { U Mann- } \\
\text { Whitney } \\
\text { test; } p\end{array}$} & \multicolumn{2}{|c|}{$\begin{array}{l}\text { The mean length } \\
(+/-\mathrm{SD}) \text { of } \\
\text { central leaf lobe } \\
\text { of basal leaves }\end{array}$} & \multirow[t]{2}{*}{$\begin{array}{l}\text { U Mann- } \\
\text { Whitney } \\
\text { test; } p\end{array}$} \\
\hline & 2013 & 2014 & & 2013 & 2014 & & 2013 & 2014 & & 2013 & 2014 & \\
\hline I & $\begin{array}{l}13.0 \\
(3.6)\end{array}$ & $\begin{array}{l}22.5 \\
(5.9)\end{array}$ & 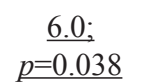 & $\begin{array}{l}10.6 \\
(3.6)\end{array}$ & $\begin{array}{l}10.8 \\
(2.9)\end{array}$ & $\begin{array}{c}-0.73 \\
p=0.46\end{array}$ & $\begin{array}{c}4.3 \\
(0.7)\end{array}$ & $\begin{array}{c}4.2 \\
(0.5)\end{array}$ & $\begin{array}{c}1.47 ; \\
p=0.14\end{array}$ & $\begin{array}{c}6.2 \\
(1.9)\end{array}$ & $\begin{array}{c}5.7 \\
(2.3)\end{array}$ & $\underline{p=} \stackrel{4.0 ;}{0.0004}$ \\
\hline II & $\begin{array}{l}12.2 \\
(2.8)\end{array}$ & $\begin{array}{l}21.2 \\
(3.4)\end{array}$ & $\underline{\underline{0.5}} \underline{0.006}$ & $\begin{array}{l}10.7 \\
(2.8)\end{array}$ & $\begin{array}{l}11.1 \\
(1.8)\end{array}$ & $\begin{array}{l}-1.22 \\
p=0.22\end{array}$ & $\begin{array}{c}4.7 \\
(0.8)\end{array}$ & $\begin{array}{c}4.8 \\
(0.4)\end{array}$ & $\begin{array}{l}-1.89 \\
p=0.06\end{array}$ & $\begin{array}{c}6.0 \\
(2.1)\end{array}$ & $\begin{array}{c}6.2 \\
(1.7)\end{array}$ & $\begin{array}{l}-2.00 \\
p=0.06\end{array}$ \\
\hline III & $\begin{array}{l}16.4 \\
(3.6)\end{array}$ & $\begin{array}{l}22.4 \\
(5.2)\end{array}$ & $\frac{20.5 ;}{p=0.08}$ & $\begin{array}{l}13.3 \\
(3.7)\end{array}$ & $\begin{array}{l}12.9 \\
(4.6)\end{array}$ & $\begin{array}{c}1.55 ; \\
p=0.11\end{array}$ & $\begin{array}{c}4.9 \\
(0.9)\end{array}$ & $\begin{array}{l}4.6 \\
(2.4)\end{array}$ & $\underline{p=0.0004}$ & $\begin{array}{c}6.9 \\
(2.3)\end{array}$ & $\begin{array}{c}7.0 \\
(1.8)\end{array}$ & $\begin{array}{l}-1.47 \\
p=0.14\end{array}$ \\
\hline IV & $\begin{array}{l}13.6 \\
(2.6)\end{array}$ & $\begin{array}{l}16.1 \\
(4.2)\end{array}$ & $\begin{array}{c}45.5 ; \\
p=0.13\end{array}$ & $\begin{array}{l}22.7 \\
(6.9)\end{array}$ & $\begin{array}{l}22.6 \\
(5.8)\end{array}$ & $\begin{array}{c}0.26 \\
p=0.78\end{array}$ & $\begin{array}{c}5.3 \\
(2.9)\end{array}$ & $\begin{array}{c}5.3 \\
(1.7)\end{array}$ & $\begin{array}{l}-0.61 ; \\
p=0.23\end{array}$ & $\begin{array}{c}6.9 \\
(1.3)\end{array}$ & $\begin{array}{l}7.0 \\
(2.5)\end{array}$ & $\begin{array}{l}-0.04 \\
p=0.96\end{array}$ \\
\hline $\mathrm{V}$ & $\begin{array}{c}4.4 \\
(0.7)\end{array}$ & $\begin{array}{c}5.6 \\
(1.7)\end{array}$ & $\begin{array}{l}120.0 \\
p=0.18\end{array}$ & $\begin{array}{l}17.9 \\
(3.8)\end{array}$ & $\begin{array}{l}16.1 \\
(5.1)\end{array}$ & $\begin{array}{c}2.27 \\
p=0.06\end{array}$ & $\begin{array}{c}6.4 \\
(2.4)\end{array}$ & $\begin{array}{c}6.3 \\
(2.8)\end{array}$ & $\begin{array}{c}1.56 ; \\
p=0.11\end{array}$ & $\begin{array}{c}7.7 \\
(1.8)\end{array}$ & $\begin{array}{l}7.3 \\
(2.7)\end{array}$ & $\underline{p=0.00001}$ \\
\hline VI & $\begin{array}{c}4.7 \\
(1.8)\end{array}$ & $\begin{array}{c}8.5 \\
(2.8)\end{array}$ & $\begin{array}{c}45.0 ; \\
p=0.16\end{array}$ & $\begin{array}{l}20.2 \\
(5.3)\end{array}$ & $\begin{array}{l}21.1 \\
(6.5)\end{array}$ & $\begin{array}{l}-0.73 \\
p=0.45\end{array}$ & $\begin{array}{c}6.2 \\
(2.3)\end{array}$ & $\begin{array}{c}6.1 \\
(2.8)\end{array}$ & $\begin{array}{c}1.59 ; \\
p=0.10\end{array}$ & $\begin{array}{c}8.3 \\
(2.4)\end{array}$ & $\begin{array}{c}8.1 \\
(2.6)\end{array}$ & $\begin{array}{c}1.43 \\
p=0.15\end{array}$ \\
\hline VII & $\begin{array}{c}7.5 \\
(2.7)\end{array}$ & $\begin{array}{c}8.3 \\
(3.7)\end{array}$ & $\begin{array}{l}50.0 \\
p=0.5\end{array}$ & $\begin{array}{l}36.0 \\
(9.2)\end{array}$ & $\begin{array}{l}35.2 \\
(6.3)\end{array}$ & $\begin{array}{c}0.54 \\
p=0.58\end{array}$ & $\begin{array}{l}7.6 \\
(2.7)\end{array}$ & $\begin{array}{c}7.3 \\
(1.7)\end{array}$ & $\begin{array}{l}2.03 ; \\
p=0.04\end{array}$ & $\begin{array}{c}8.6 \\
(2.8)\end{array}$ & $\begin{array}{c}8.9 \\
(2.9)\end{array}$ & $\begin{array}{c}-0.90 \\
p=0.36\end{array}$ \\
\hline VIII & $\begin{array}{c}3.5 \\
(0.3)\end{array}$ & $\begin{array}{c}6.4 \\
(1.6)\end{array}$ & $\underline{23.0 ;}$ & $\begin{array}{l}19.7 \\
(3.5)\end{array}$ & $\begin{array}{l}19.6 \\
(4.9)\end{array}$ & $\begin{array}{c}-0.28 \\
p=0.77\end{array}$ & $\begin{array}{c}6.9 \\
(2.9)\end{array}$ & $\begin{array}{c}7.1 \\
(1.8)\end{array}$ & $\frac{-2.05}{p=0.04}$ & $\begin{array}{c}7.9 \\
(2.8)\end{array}$ & $\begin{array}{c}8.2 \\
(2.9)\end{array}$ & $\begin{array}{l}-2.09 \\
p=0.06\end{array}$ \\
\hline
\end{tabular}

Explanation: the statistically significant values are underlined
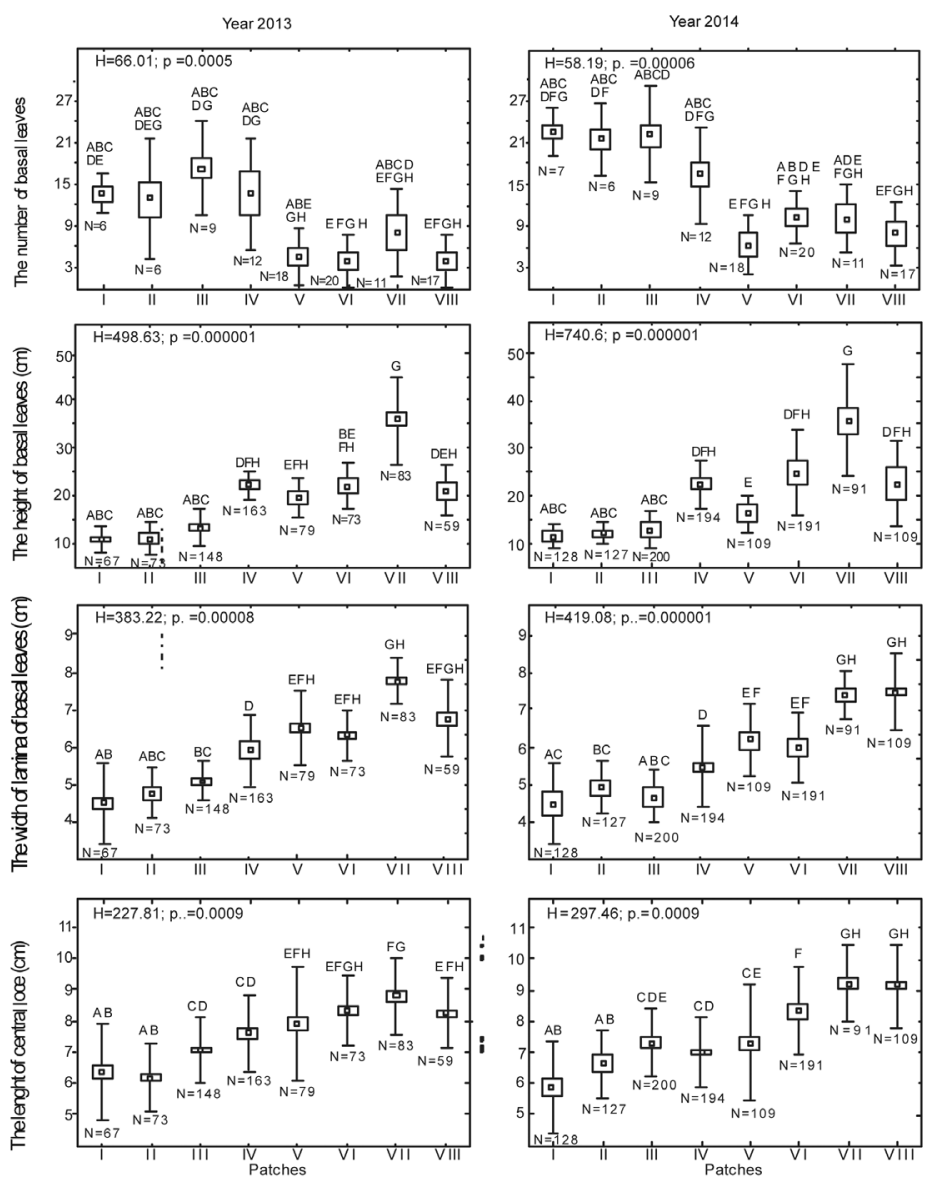

Fig. 3. The spatial variability of number and height, lamina width and length of a central lamina lobe of basal leaves in populations of Trollius europaeus L. occurring in: Molinietum caeruleae meadow dominated by small meadow species, frequently disturbed by trampling and burrowing (patch I), abandoned Molinietum caeruleae meadows in different stages of overgrowing (patches II-VI), and on the edge (patch VII) and in the interior (patch VIII) of birch woodlot in the years 2013-2014 
Table 5. The temporal variability of number and height of generative stems, number of flowers per generative stem and number of follicles per multifollicle in populations of Trollius europaeus L. occurring in: Molinietum caeruleae meadow dominated by small meadow species, frequently disturbed by trampling and burrowing (patch I), abandoned Molinietum caeruleae meadows in different stages of overgrowing (patches II-VI), and on the edge (patch VII) and in the interior (patch VIII) of birch woodlot in the years 2013-2014

\begin{tabular}{|c|c|c|c|c|c|c|c|c|c|c|c|c|}
\hline \multirow[t]{2}{*}{ Patch } & \multicolumn{2}{|c|}{$\begin{array}{c}\text { The mean } \\
\text { number }(+/-\mathrm{SD}) \\
\text { of generative } \\
\text { stems }\end{array}$} & \multirow[t]{2}{*}{$\begin{array}{l}\text { U Mann- } \\
\text { Whitney } \\
\text { test; } p\end{array}$} & \multicolumn{2}{|c|}{$\begin{array}{c}\text { The mean } \\
\text { height }(+/-\mathrm{SD}) \\
\text { of generative } \\
\text { stems }\end{array}$} & \multirow[t]{2}{*}{$\begin{array}{l}\text { U Mann- } \\
\text { Whitney } \\
\text { test; } p\end{array}$} & \multicolumn{2}{|c|}{$\begin{array}{l}\text { The mean } \\
\text { number }(+/-\mathrm{SD}) \\
\text { of flowers per } \\
\text { generative stem }\end{array}$} & \multirow[t]{2}{*}{$\begin{array}{l}\text { U Mann- } \\
\text { Whitney } \\
\text { test; } p\end{array}$} & \multicolumn{2}{|c|}{$\begin{array}{l}\text { The mean } \\
\text { number (+/-SD) } \\
\text { of follicles per } \\
\text { multifollicle }\end{array}$} & \multirow[t]{2}{*}{$\begin{array}{l}\text { U Mann- } \\
\text { Whitney } \\
\text { test; } p\end{array}$} \\
\hline & 2013 & 2014 & & 2013 & 2014 & & 2013 & 2014 & & 2013 & 2014 & \\
\hline I & $\begin{array}{c}4.3 \\
(1.2)\end{array}$ & $\begin{array}{c}5.2 \\
(2.1)\end{array}$ & $\begin{array}{c}15.0 \\
p=0.68\end{array}$ & $\begin{array}{l}10.4 \\
(2.9)\end{array}$ & $\begin{array}{l}11.3 \\
(3.9)\end{array}$ & $\begin{array}{l}-1.62 \\
p=0.10\end{array}$ & $\begin{array}{l}1.1 \\
(0.6)\end{array}$ & $\begin{array}{c}1.1 \\
(0.4)\end{array}$ & $\begin{array}{l}-0.10 \\
p=0.91\end{array}$ & $\begin{array}{l}10.6 \\
(2.7)\end{array}$ & $\begin{array}{l}14.8 \\
(4.7)\end{array}$ & $\begin{array}{c}\frac{-3.38}{p=0.0007} \\
\end{array}$ \\
\hline II & $\begin{array}{c}9.5 \\
(2.9)\end{array}$ & $\begin{array}{l}11.3 \\
(5.2)\end{array}$ & $\begin{array}{c}10.5 \\
p=0.26\end{array}$ & $\begin{array}{l}13.4 \\
(4.2)\end{array}$ & $\begin{array}{l}16.6 \\
(5.1)\end{array}$ & $\underline{p=0.0003}$ & $\begin{array}{l}1.2 \\
(0.6)\end{array}$ & $\begin{array}{c}1.2 \\
(0.7)\end{array}$ & $\begin{array}{c}-0.39 \\
p=0.69\end{array}$ & $\begin{array}{l}12.5 \\
(3.2)\end{array}$ & $\begin{array}{l}14.4 \\
(5.9)\end{array}$ & $\frac{-3.22 ;}{p=0.001}$ \\
\hline III & $\begin{array}{c}5.8 \\
(1.9)\end{array}$ & $\begin{array}{c}6.5 \\
(2.6)\end{array}$ & $\begin{array}{c}21.5 \\
p=0.74\end{array}$ & $\begin{array}{l}17.2 \\
(3.5)\end{array}$ & $\begin{array}{l}22.0 \\
(6.9)\end{array}$ & $\frac{-3.11}{p=0.001}$ & $\begin{array}{c}1.2 \\
(0.9)\end{array}$ & $\begin{array}{c}1.5 \\
(1.1)\end{array}$ & $\begin{array}{l}-0.95 \\
p=0.34\end{array}$ & $\begin{array}{c}6.9 \\
(1.3)\end{array}$ & $\begin{array}{l}11.2 \\
(3.8)\end{array}$ & $\begin{array}{c}-2.84 ; \\
p=0.001\end{array}$ \\
\hline IV & $\begin{array}{c}2.7 \\
(0.8)\end{array}$ & $\begin{array}{c}3.2 \\
(0.7)\end{array}$ & $\begin{array}{c}56.5 \\
p=0.87\end{array}$ & $\begin{array}{l}22.9 \\
(5.9)\end{array}$ & $\begin{array}{l}26.0 \\
(7.4)\end{array}$ & $\begin{array}{l}-1.00 \\
p=0.31\end{array}$ & $\begin{array}{l}1.2 \\
(0.4)\end{array}$ & $\begin{array}{c}1.3 \\
(0.6)\end{array}$ & $\begin{array}{c}0.05 \\
p=0.95\end{array}$ & $\begin{array}{l}12.5 \\
(3.7)\end{array}$ & $\begin{array}{l}13.9 \\
(4.1)\end{array}$ & $\begin{array}{l}-1.37 \\
p=0.16\end{array}$ \\
\hline $\mathrm{V}$ & $\begin{array}{c}1.8 \\
(0.5)\end{array}$ & $\begin{array}{c}2.1 \\
(0.7)\end{array}$ & $\begin{array}{l}130.0 \\
p=0.62\end{array}$ & $\begin{array}{l}27.8 \\
(5.9)\end{array}$ & $\begin{array}{l}30.2 \\
(7.9)\end{array}$ & $\begin{array}{l}-1.23 \\
p=0.21\end{array}$ & $\begin{array}{l}1.2 \\
(0.6)\end{array}$ & $\begin{array}{c}1.5 \\
(0.6)\end{array}$ & $\begin{array}{c}-0.77 \\
p=0.43\end{array}$ & $\begin{array}{l}14.1 \\
(3.8)\end{array}$ & $\begin{array}{l}14.5 \\
(4.6)\end{array}$ & $\begin{array}{c}-0.43 \\
p=0.66\end{array}$ \\
\hline VI & $\begin{array}{l}1.5 \\
(0.8)\end{array}$ & $\begin{array}{c}1.8 \\
(0.5)\end{array}$ & $\begin{array}{l}163.0 \\
p=0.61\end{array}$ & $\begin{array}{l}24.4 \\
(5.9)\end{array}$ & $\begin{array}{l}33.3 \\
(7.2)\end{array}$ & $\begin{array}{c}\underline{-5.38} \\
p=0.0002 \\
\end{array}$ & $\begin{array}{l}1.6 \\
(0.5)\end{array}$ & $\begin{array}{c}1.5 \\
(0.6)\end{array}$ & $\begin{array}{c}0.35 \\
p=0.72\end{array}$ & $\begin{array}{l}15.1 \\
(5.7)\end{array}$ & $\begin{array}{l}18.8 \\
(6.1)\end{array}$ & $\begin{array}{c}\underline{-3.35} \\
p=0.0007\end{array}$ \\
\hline VII & $\begin{array}{c}4.6 \\
(1.2)\end{array}$ & $\begin{array}{c}5.3 \\
(1.3)\end{array}$ & $\begin{array}{c}54.0 ; \\
p=0.69\end{array}$ & $\begin{array}{l}47.6 \\
(8.4)\end{array}$ & $\begin{array}{l}43.8 \\
(9.3)\end{array}$ & $\begin{array}{c}1.79 ; \\
p=0.07\end{array}$ & $\begin{array}{l}1.6 \\
(0.5)\end{array}$ & $\begin{array}{c}1.9 \\
(1.3)\end{array}$ & $\begin{array}{c}-1.69 \\
p=0.09\end{array}$ & $\begin{array}{l}22.4 \\
(8.3)\end{array}$ & $\begin{array}{l}23.6 \\
(8.1)\end{array}$ & $\begin{array}{l}\frac{-2.10}{p=0.03} \\
\end{array}$ \\
\hline VIII & $\begin{array}{l}1.5 \\
(0.4)\end{array}$ & $\begin{array}{c}1.4 \\
(0.8)\end{array}$ & $\begin{array}{l}144.5 \\
p=0.91\end{array}$ & $\begin{array}{l}45.9 \\
(9.4)\end{array}$ & $\begin{array}{l}36.5 \\
(5.3)\end{array}$ & $\underline{3.78 ;}$ & $\begin{array}{c}1.9 \\
(0.7)\end{array}$ & $\begin{array}{l}1.8 \\
(0.6)\end{array}$ & $\begin{array}{c}0.38 \\
p=0.79\end{array}$ & $\begin{array}{l}22.2 \\
(5.0)\end{array}$ & $\begin{array}{l}20.3 \\
(7.3)\end{array}$ & $\frac{2.12 ;}{p=0.03}$ \\
\hline
\end{tabular}

Explanation: the statistically significant values are underlined
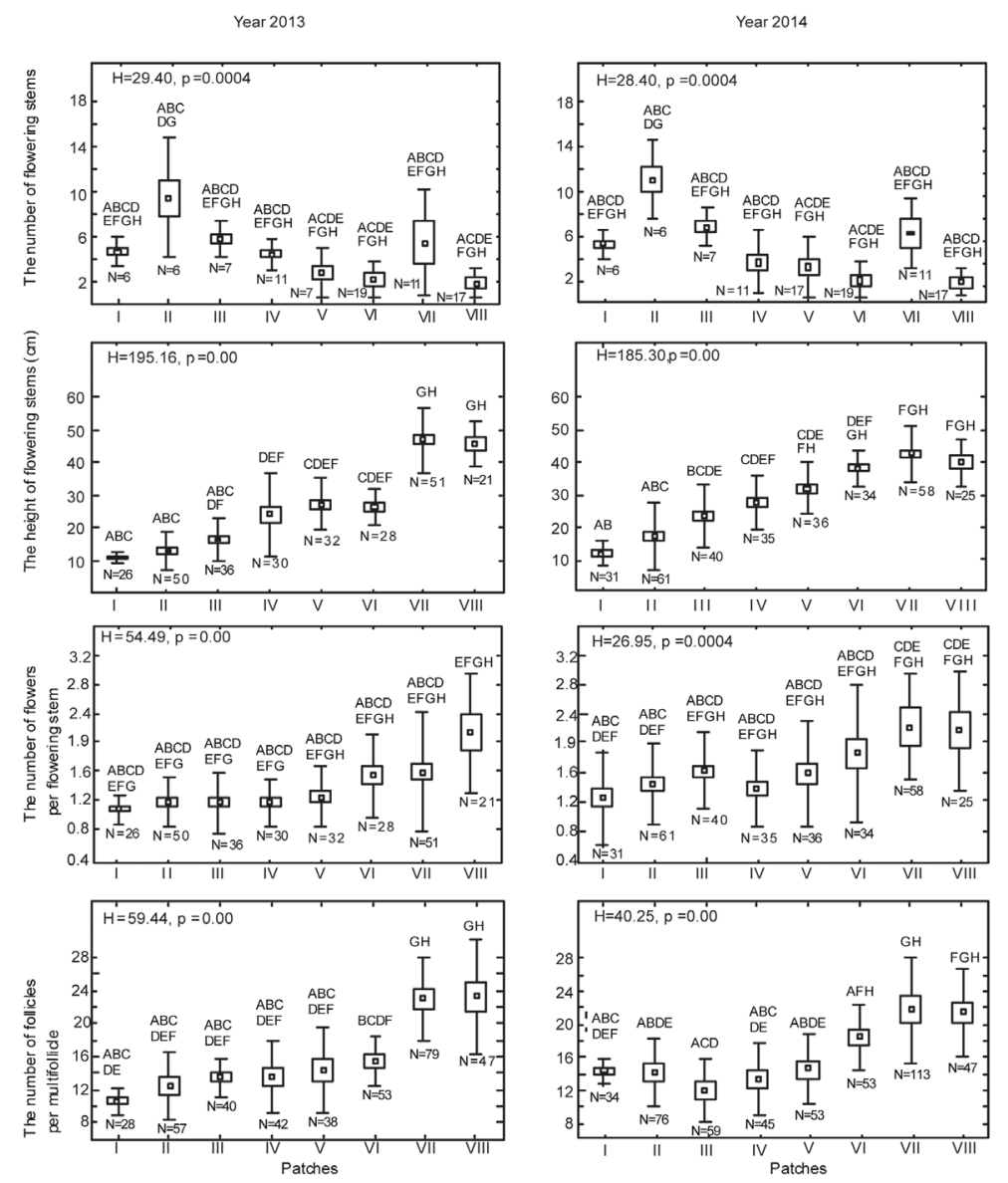

Fig. 4. The spatial variability of number and height of generative stems, number of flowers per generative stem and number of follicles per multifollicle in populations of Trollius europaeus L. occurring in Molinietum caeruleae meadow dominated by small meadow species, frequently disturbed by trampling and burrowing (patch I), abandoned Molinietum caeruleae meadows in different stages of overgrowing (patches II-VI), and at the edge (patch VII) and in the interior (patch VIII) of birch woodlot in the years 2013-2014 


\section{Discussion}

\subsection{Habitat conditions in studied patches}

The different habitat conditions observed in successive patches were the consequence of varying species composition across the successional gradient. The rise in the mean height of standing vegetation in abandoned Molinia meadows, a consequence of the successive encroachment of tall-growing grasses, shrubs and trees, was observed repeatedly in the course of meadow overgrowth (Michalska-Hejduk \& Kopeć 2012; Sienkiewicz-Paderewska et al. 2012; Warda et al. 2013). The height and architecture of dominant species in the plant canopy influenced light availability at ground level. The predominance of low-growing rosette taxa and small-tussock grasses and sedges enabled substantial penetration of light and its considerable availability at soil level. Light availability diminished gradually in patches dominated by large-tussock graminoids, shrubs and trees, and achieved the lowest values in woodlots. A similar phenomenon was observed in abandoned fens by Jensen \& Schrautzer (1999) and Opdekamp et al. (2012). The gradual rise in soil moisture in successive patches observed in the present study may be the result of the dominance of multi-shoot tall-growing plants producing substantial amounts of litter, thus becoming a natural barrier against water evaporation. Such a scenario was observed previously in Molinia meadows (Kącki \& Michalska-Hejduk 2010; Kulik 2014).

\subsection{Abundance and developmental structure of subpopulations}

The substantial frequency of juvenile individuals in the subpopulation of $T$. europaeus established in patch I in contrast to the other sites may be linked with recruitment of seedlings in gaps in the plant cover and litter appearing following trampling and grazing by animals. The abundant colonisation of openings in swards by seedlings of T. europaeus was observed previously by several authors (Hitchmough 2003; Vandvik 2004; Kochanowska \& Gamrat 2007; KostrakiewiczGieralt 2012). At the same time, it should be pointed out that the role of disturbances as safe sites for the recruitment of clonal plant seedlings in meadows was demonstrated repeatedly (Eriksson 1997; Borkowska 2004; Kostrakiewicz-Gierałt 2014a). On the other hand, animal activities such as wallowing, trampling and browsing may lead to uprooting genets of T. europaeus or damage to their above-ground parts. This scenario was observed over a wide range of habitats from meadows and grasslands (Hulme 1994; Edwards \& Crawley 1999) through shrublands (Bestelmeyer et al. 2007) to forests (Gillman \& Ogden 2003; Simonetti et al. 2007; Goodale et al. 2014). At the same time, it should be added that, due to their poisonous nature (Wink 2009), seedlings of T. europaeus may be less prone to becoming victims of grazing. The non-palatability of other species of the Ranunculaceae family was shown repeatedly (Lamoureaux \& Bourdôt 2007; Lusk et al. 2009).

Despite the lack of juveniles and low abundance, the constant number of $T$. europaeus ramet clusters observed in the other patches (II-VIII) throughout the study period may suggest the ability to persist in successional consecutive communities. This phenomenon, possibly due to multi-shoot architecture, longevity of underground organs and dual reproductive mode (Falińska 1989a) was also recorded in populations of other species inhabiting humid meadows such as Dianthus superbus (Kostrakiewicz-Gierałt 20014b), Filipendula ulmaria (Falińska 1989a, 1989b, 1991, 2010), Iris pseudacorus (Falińska 1991), Lysimachia vulgaris, and Lythrum salicaria (Falińska 1989a, 1989b).

\subsection{Number and dimensions of basal leaves}

The lack of temporal variability in the number of T. europaeus basal leaves observed in patches dominated by strong competitors such as shrub willows, tall-growing tussock and rhizomatous grasses or trees may be linked with a lack of available space necessary for the clonal proliferation of ramets. The increase in the number of basal leaves at other sites may be due to the unlimited iterative growth of ramet clusters growing in the vicinity of small meadow species or situated at considerable distances from adjacent plants in woodlot undergrowth. The observed spatial variability manifested in the lesser production of basal leaves in overgrown meadows and woodlots is not consistent with the study of Juśkiewicz-Swaczyna et al. (2008), who recorded an inverse tendency.

The lack of temporal variability and the substantial spatial variability of the heights of leaf petioles and dimensions of leaf blades found in several subpopulations of T. eurapaeus is in accord with observations carried out in populations of Gladiolus imbricatus (Kostrakiewicz-Gierałt 2014b). The increasing dimensions of leaf blades of $T$. europaeus from patch I to VII, which may be linked with augmentation of lateral shade, supports previous studies carried out in natural (Kostrakiewicz 2009) and laboratory conditions (Klank et al. 2012). Contrastingly, Kochanowska \& Gamrat (2007) found that petioles achieved greater heights in mowed patches than in abandoned meadows. The slight decrease in the dimensions of basal leaves of T. europaeus noted in patch VIII may be due to full shade from above created by surrounding trees and shrubs. The results correspond to those of an experiment conducted by Semchenko et al. (2012) who found that strong shade hampers growth and development of several taxa inhabiting temperate grasslands. 
4.4. Number and height of generative stems and flower and fruit production

The lack of temporal variability and the presence of substantial spatial variability in the number and height of generative stems as well as the number of flowers found in many subpopulations of T. europaeus is in keeping with observations carried out in populations of other meadow taxa such as Gladiolus imbricatus (Kostrakiewicz-Gierałt 2014b) and Dianthus superbus (Kostrakiewicz-Gierałt 2014c). The large generative stems and considerable flower production noted in T. europaeus occurring in overgrown meadows and woodlots may result in an increase in the visibility of inflorescences and their attractiveness to pollinators, while greater fruit production may enhance chances for the successful dispersal of light seeds. The obtained results are in opposition to the findings of Kochanowska \& Gamrat (2007). Moreover, a greenhouse experiment (Scanga 2011) and field observations (Jones \& Klemetti 2012; Scanga \& Leopold 2012) showed that the performance of the closely-related species Trollius laxus increased with increasing light levels and decreasing soil moisture.

The performed observations, showing strong temporal and spatial variability of follicle number, suggest a successful process of pollination in patches I-VII and insufficient pollinator visits to patch VIII. Heretofore, scanty fruit production as a consequence of a lack of pollinator visits has been observed over a wide spectrum of habitats (Klein et al. 2007; Ågren et al. 2008; Thomson 2010). At the same time, it should be pointed out that even considerable fruit production by ramet clusters of T. europaeus might not assure the increase of abundance of subpopulations due to the short period of seed viability (Milberg 1994).

\subsection{Implications for population management}

The low level of subpopulation abundance, small number and dimensions of ramets, and moderate production of flowers and infructescences all indicate the weak condition of the subpopulation occurring in patch I. Even considerable seedling recruitment does not guarantee the long-term persistence of a subpopulation in a colonised area. The state of the subpopulation might be improved by limitation of animal activities following a period of seedling recruitment. Surrounding of the above-mentioned patch from late spring till autumn using demountable fence seems to be necessary for maintenance of subpopulation T. eurapaeus in the colonized site. The considerable number and height of basal leaves and generative stems might suggest a satisfactory condition of the ramet clusters growing in patches II-VIII; on the other hand, substantial flower and fruit production might be insufficient to sustain subpopulations in the occupied sites. Improvement in the condition of these subpopulations might be achieved by intermediated, controlled management. The best solution seems to be artificial, moderate removal of the plant canopy and litter layer resulting in the appearance of small gaps which would serve as safe sites for seedling recruitment. The establishment of recruits might contribute to prolonged maintenance of subpopulations in the occupied sites.

\section{References}

Ågren J., Ehrlén J. \& Solbreck Ch. 2008. Spatio-temporal variation in fruit production and seed predation in a perennial herb influenced by habitat quality and population size. J. Ecol. 96(2): 334-345. http://dx.doi. org./10.1111/j.1365-2745.2007.01334.x

Antкоwiak W. 1999. Ecological structure of Trollius europaeus L. subsp. europaeus in northwestern Poland. Rocz. AR. Pozn. 346, Bot. 2: 3-17.

AntKowiak W. 2002. Interpopulation variability of globe flower (Trollius europaeus L. subsp. europaeus) in north-western Poland. Rocz. AR. Pozn. 347, Bot 5: 3-4.

Antkowiak W. \& Maciejewska I. 1999. Structure and morphological variability of flowers of globe flower (Trollius europaeus L.). Bibliotheca Fragmenta Agronomica 6: 97-105.

Benkert D. \& Klem G. (eds.) 1993. Rote Liste Farn- und Blütenpflanzen In: Rote Liste. Gefährdete Farn- und Blütenpflanzen, Algen und Pilze im Land Branden- burg, pp: 7-95. Ministerium für Umwelt, Naturschutz und Raumordnung des Landes Branderburg, Unze, Potsdam.

Bestelmeyer B. T., Kalil N. I. \& Peters D. P. C. 2007. Does shrub invasion indirectly limit grass establishment via seedling herbivory? A test at grassland-shrubland ecotones. J. Veg. Sci. 18(3): 363-370. http://dx.doi. org/10.1658/1100-233(2007)18[363:DSIILG]2.0.CO;2

Bernacki L., Nowak T., Urbisz A., Urbisz A. \& TokarskaGuzik B. 2000. Rośliny chronione, zagrożone i rzadkie we florze województwa śląskiego. Acta Biol. Siles. 35(52): 78-107.

BorkowsKa L. 2004. Patterns of seedling recruitment in experimental gaps on mosaic vegetation in abandoned meadow. Acta Soc. Bot. Pol. 73: 343-350. http://dx.doi. org/10.5586/asbp.2004.045

Cheffings Ch. M. \& Farrel L. (eds.) 2005. The Vascular Plants Red Data List for Great Britain. Species status 
7: 1-116. Join Nature Conservation Committee, Peterborough.

Curtis T. G. F. \& McGough M. H. 1988. The Irish Red Data Book. 1. Vascular Plants, pp. 168. Wildlife Service Ireland, Dublin

DoroszewsKa A. 1974. The genus Trollius L. A taxonomical study. Mon. Bot. 41:1-151.

Dubiel E. 1991. Map of actual vegetation of the city of Cracow. Zesz Nauk UJ, Prace Bot. 22: 121-133.

Dubiel E. 1996. Meadows in Cracow. I. Molinio-Arrhenatheretea class. Studia Ośr. Dok. Fizjogr. PAN 24: 145-171.

Dubiel E. 2005. Map of plant communities of the 3rd Campus of The Jagiellonian University and its surroundings. Institute of Botany UJ, Kraków

Edwards G. R. \& Crawley M. J. 1999. Effects of disturbance and rabbit grazing on seedling recruitment of six mesic grassland species. Seed Sci. Res. 9: 145-156.

ERIKSSON O. 1997. Clonal life histories and the evolution of seed recruitment. In: H. DE KROON \& J. van GROENENDAEL (eds.). The ecology and evolution of clonal plants, pp. 211-226. Backhuys Publishers, Leiden.

FALIŃSKA K. 1989a. Plant population process in the course of forest succession in abandoned meadows. II. Demography of succession promotors. Acta Soc. Bot. Pol. 58(3): 467-491. http://dx.doi.org/10.5586/ asbp. 1989.037

FALIŃSKA K. 1989b. Plant population process in the course of forest succession in abandoned meadows. I. Variability and diversity of floristic compositions, and biological mechanism of species turnover. Acta Soc. Bot. Pol. 58(3): 439-465. http://dx.doi.org/10.5586/ asbp. 1989.037

FALIŃSKA K. 1991. Plant demography in vegetation succession. Task for Vegetation Science 26, 210 pp. Kluwer Academic Publishers, Dordrecht.

FALIŃSKA K. 2010. Patterns of genetic diversity in populations of Filipendula ulmaria (L.) at different stages of succession on a meadow abandoned for 30 years. Pol. J. Ecol. 58(1): 27-40.

Gillman L. N. \& Ogden J. 2003. Seedling mortality and damage due to non-trophic animal interactions in a northern New Zeland forest. Austral Ecology 28: 48-52.

GŁowacki Z., Falkowski M., Krechowski J., Marciniuk J., Marciniuk P., Nowicka-Falkowska K. \& Wierzba M. 2003. Czerwona lista roślin naczyniowych Niziny Południowopodlaskiej. Chrońmy Przyr. Ojcz. 59(2): 5-41.

Goodale U. M., Berlyn G. P., Gregoire T. G., Tennakoon K. U. \& Ashton M. S. 2014. Differences in survival and growth among tropical rain forest pioneer tree seedlings in relation to canopy openness and herbivory. Biotropica 46(2): 183-193. http://dx.doi.org./10.1111/ btp. 12088

Hitchmough J. D. 2003. Effects of sword height, gap size and slug grazing on emergence and establishment of Trollius europaeus (Globeflower). Rest. Ecol. 11: 20-28. http://dx.doi.org./10.1016/j.flora.2004.08.003

Hulme P. E. 1994. Seedling herbivory in grassland: relative impact of vertebrate and invertebrate herbivores.
J. Ecol. 82(4): 873-880. http://dx.doi.org./10.2307/ 2261451

Hultén E. \& Fries M. 1986. Atlas of North European Vascular Plants. North of the Tropic of Cancer. I. Introduction, taxonomic index to the maps 1-996. Maps 1-996. xvi+498 pp. Koeltz Scientific Books, Königstein.

Ingelög T., Andersson R. \& TJenberg M. 1993. Red Data Book of The Baltic Region. Part 1 Lists of threatened vascular plants and vertebrates. $95 \mathrm{pp}$. Swedish Threatened Species Unit, Uppsala, Institute of Biology, Riga.

Jackowiak B., Celka Z., Chmiel J., Latowski K. \& Żukowski W. 2007. Red list of vascular flora of Wielkopolska (Poland). Biodiv. Res. Conserv. 5-8: 95-127.

JAEGER N. \& L. Despres 1998. Obligate mutualism between Trollius europaeus and its seed-parasite pollinators Chiastocheta flies in the Alps. Comptes Rendus de l'Academie des Sciences Serie III Sciences de la Vie 321: 789-796. http://dx.doi.org./10.1016/S07644469(98)80019-X

JAGODZIŃSKi A. M., MACIEJEWSKA-RUTKOWSKA I. \& ANTKOWIAK W. 2008. Morphological variability of leaves of Trollius europaeus L. originated from Wielkopolska province (Western Poland). Rocz. AR Pozn. 387, Botanica-Steciana 12: 129-133.

JAKUBOWSKA-GABARA J. \& KUCHARSKI L. 1999. Ginące i zagrożone gatunki flory naczyniowej zbiorowisk naturalnych i półnaturalnych Polski Środkowej. Frag. Flor. Geobot. Polonica: 6: 55-64.

Jensen K. \& Schrautzer J. 1999. Consequences of abandonment for a regional fen flora and mechanisms of successional change. Appl. Veg. Sci. 2: 79-88.

Jones K. N. \& Klemetti S.M. 2012. Managing marginal population of rare wetland plant Trollius laxus Salisbury (Spreading Globeflower); consideration of light level, herbivory and pollination. Northeastern Naturalist 19(2): 267-278. http://dx.doi. org/10.1656/045.019.0209

JuśKiewicz-Swaczyna B., Endler Z. \& SzczęSNa S. 2008. Structure of a population of Trollius europaeus L. at a locality near Barczewo on the Olsztyn Lakeland. Pol. J. Natur. Sc.23(3): 598-610.

KĄCKi Z., DAJdOK Z. \& SzCZĘŚNIAK E. 2003. Wykaz gatunków wymarłych, krytycznie zagrożonych, wymierających i narażonych oraz rzadkich Dolnego Śląska, In: Z. KĄCKI (ed.). Zagrożone gatunki flory naczyniowej Dolnego Śląska, pp. 9-64. Instytut Biologii Roślin Uniwersytetu Wrocławskiego, Polskie Towarzystwo Ochrony Przyrody „Pro Natura” Wrocław.

KąCKi Z. \& Michalaska-Hejduk D. 2010. Assessment of biodiversity in Molinia meadows in Kampinoski National Park based on biocenotic indicators. Pol. J. Environ. Stud. 19(2): 351-362.

KIRÁly G. (ed.) 2007. Red List of the Vascular flora in Hungary. 73 pp. Saját kiadás, Sopron.

Klein A-M., Vaissière B. E., Cane J. H., Steffan-Dewenter I., Cunningham S. A., Kremen C. \& Tscharntke T. 2007. Importance of pollinators in changing landscapes for world crops. Proc Biol Sci. 274(1608): 303-313. http://dx.doi.org/10.1098/rspb.2006.3721 
Kochanowska P. \& GamRat R. 2007. Grass communities with globe flower (Trollius europaeus L.) in the river Chociel valley. Grassland Science in Poland 10: 119-129.

Kostrakiewicz K. 2009. The influence of shadow created by adjacent plants on phenotypic plasticity of endangered species Trollius europaeus L. (Ranunculaceae). Pol. J. Ecol. 57(4): 625-634.

Kostrakiewicz-GieraŁt K. 2012. The impact of neighbourhood and gap character on seedling recruitment of Trollius europaeus L. and Iris sibirica L. in Molinietum caeruleae meadows. Biodiv. Res. Conserv. 28: 37-44. http://dx.doi.org./10.2478/v10119-012-0026-1

Kostrakiewicz-Gieratt K. 2014a. The effects of successional stage and size of gaps on recruitment of clonal plants in overgrowing Molinietum caeruleae meadows. Acta Agrobot. 67(4): 87-98. http://dx.doi.org/10.5586/ aa.2014.044

Kostrakiewicz-Gierąt K. 2014b. The variability of selected features of Gladiolus imbricatus L. in relation to successive stages of meadow communities following the mowing cessation. Pol. J. Ecol. 62:307-321.

Kostrakiewicz-Gieraet K. 2014c. The life-history traits influencing reproduction success and seedling recruitment of Dianthus superbus L. in different stages of meadow overgrowing. Acta Agrobot. 67(2); 23-29. http://dx.doi.org/10.5586/aa.2014.022

Klank C., Ghazoul J. \& Pluess A. R. 2012. Genetic variation and plant performance in fragmented populations of globeflowers (Trollius europaeus) within agricultural landscapes. Conservation Genetics 13(3): 873-884.

Kopeć D. \& Michalska-Hejduk D. 2012. How threatened in Polish wetland flora? Oceanological and Hydrobiological Studies 41(3): 79-89. http://dx.doi.org./10.2478/ s13545-012-0030-2

KuLIK M. 2014. Changes in biodiversity and species composition of Molinia meadow depending on use method. Pol. J. Environ. Stud. 23(3): 773-782.

Lamoureaux S.L. \& Bourdôt G.W. 2007. A review of the ecology and management of Ranunculus acris subsp acris in pasture. Weed Res. 47(60: 461-471. http:// dx.doi.org/10.1111/j.1365-3180.2007.00588.x

Lusk C. S., Lamoureaux S. L. \& Bourdôt G. W. 2009. Giant buttercup (Ranunculus acris L.) seedling emergence and survival in golden bay dairy pastures. New Zealand Plant Protection 62: 222-227.

Matuszkiewicz W. 2001. Przewodnik do oznaczania zbiorowisk roślinnych Polski. In: J. B. FALiŃski (ed.). Vademecum Geobotanicum 3, 537 pp. Wyd. Nauk. PWN, Warszawa.

Michalska-Hejduk D. \& Kopeć D. 2012. Dynamics of seminatural vegetation with a focus on Molinion meadows after 50 years of strict protection. Pol. J. Environ. Stud. 21(6): 1731-1741.

Milberg P. 1994. Germination ecology of the polycarpic grassland perennials Primula veris and Trollius europaeus. Ecography 17: 3-8.

Moser D., Gygax A., Bäumler B., Wyler N. \& Palese R. 2002. Liste Rouge des fougères et plantes à fleurs menacées de Suisse. 118 pp. Office fédéral de l'environnement, des forêts et du paysage, Berne,
Centre du Réseau Suisse de Floristique, Chambésy, Conservatoire et Jardin botaniques de la Ville de Genève, Chambésy. Série OFEFP “L’environnement pratique".

Muncaciu S., Gafta D., Cristea V., Rosca-Casian O. \& GoIA I. 2010. Eco-coenotic conditions and structure of Trollius europaeus L. populations in an extrazonal habitat complex (Transylvanian Carpathian foothills). Flora 205(11): 711-720. http://dx.doi.org./10.1016/j. flora.2010.04.017

Nowak A. 2002. Pełnik europejski Trollius europaeus L. In: A. NowaK A., K. SpaŁeK (ed.). Czerwona Księga Roślin Województwa Opolskiego, p. 90. OTPN, Opole.

Opdekamp W., Beauchard O., Backx H., Franken F., Cox T. J. S., van Diggelen R. \& Meire P. 2012. Effects of mowing cessation and hydrology on plant trait distribution in natural fen meadows. Acta Oecol. 39: 117127. http://dx.doi.org./10.1016/j.actao.2012.01.011

Pellmyr O. 1992. The phylogeny of a mutualism: evolution and coadaptation between Trollius and its seed-parasitic pollinators. Biol. J. Linn. Soc. 47: 337-365. http:// dx.doi.org./10.1111/j.1095-8312.1992.tb00674.x

Petrova A. \& Vladimirov V. (eds.) 2009. Red list of Bulgarian vascular plants. Phytologia Balcanica 15(1): 63-94.

Pięroś-Mirkowa H. \& Mirek Z 2003. Flora of Poland. Atlas of protected plants. $614 \mathrm{pp}$. Wyd. Multico, Oficyna Wydawnicza, Warszawa.

Rabinowitz D. 1981. Seven forms of rarity. In: H. Synge (ed.). The biological aspects of rare plant conservation, pp. 205-217. John Wiley, Chichester, UK.

Rabinowitz, D., Cairns S. \& Dillon T. 1986. Seven forms of rarity and their frequency in the flora of the British Isles. In. M. E. Soule (ed.). Conservation Biology, pp. 182-204. The Science of Scarcity and Diversity, Sinauer.

REgulation 2014. Regulation of the Minister of Environment of 9 October 2014 on wild species of plants under protection. Journal of Laws, item 1409.

SCANGA S. E. 2011. Effects of light intensity and groundwater level on the growth of a globally rare fen plant. Wetlands 31(4): 773-781. http://dx.doi.org/10.1007/ s13157-011-0194-3

Scanga S. E. \& Leopold D.J. 2010. Population vigor of a rare, wetland, understory herb in relation to light and hydrology. Torrey Bot. Soc. 137(2-3): 297-311. http:// dx.doi.org/10.3159/09-RA-047R1.1

SCANGA S. E. \& Leopold D.J. 2012. Managing wetland plant populations: Lessons learned in Europe may apply to North American fens. Biol. Conserv. 148(1): 69-78. http://dx.doi.org/10.1016/j.biocon.2012.01.061

Semchenko M., Lepik M., GotZenberger L. \& Zobel K. 2012. Positive effect of shade on plant growth: amelioration of stress or active regulation of growth rate? J. Ecol. 100(2): 459-466. http://dx.doi.org/10.1111/j.13652745.2011.01936.x

Sienkiewicz-Paderewska D., Borawska-JarmuŁowicz B., Mastalerczuk G., Chodkiewicz A. \& Stypiński P. 2012. Wpływ zaprzestania koszenia na roślinność 
łąki trzęślicowej (Molinietum caeruleae). WodaŚrodowisko-Obszary Wiejskie, 12(1): 167-179.

Simonetti J. A., Grez A. A., Celis-Diez J. L. \& Bustamante R. O. 2007. Herbivory and seedling performance in a fragmented temperate forest of Chile. Acta Oecol. 32(3): 312-318. http://dx.doi.org./10.1016/j. actao.2007.06.001

STATISTICA StatSoft Inc. 2010. STATISTICA User's Guide, Version 10 Fulsa (eds. StatSoft Polska) StatSoft Inc., Kraków.

Thomson J. D. 2010. Flowering phenology, fruiting success and progressive deterioration of pollination in an early-flowering geophyte. Phil. Trans. R. Soc. B. 365: 3187-3199. http://dx.doi.org/10.1098/rstb.2010.0115

WINK M. 2009. Mode of action and toxicology of plant toxins and poisonous plants. Mitt. Julius Kühn-Inst. 421: 93-112.
VANDVIK V. 2004. Gap dynamics in perennial subalpine grasslands: trends and processes change during secondary succession. J. Ecol. 92(1): 86-96. http://dx.doi. org./10.1111/j.1365-2745.2004.00842.x

Warda M., Stamirowska-KrzaczeK E. \& Kulik M. 2013. Floristic diversity of selected plant communities on extensive and abandoned grasslands in the Nadwieprzański Landscape Park. J. Water Land Dev. 19: 77-82.

Ziman S. N. 1983. About comparative morphology and phylogeny of genus Trollius (Ranunculaceae). Botanicheskii Zhurnal 68(4): 483-491.

ZARZYCKI K. \& SZELĄG Z. 2006. Red list of the vascular plants in Poland. In: Z. Mirek, K. Zarzycki, W. WoJewodA \& Z. Szeląg (eds.). Red list of plants and fungi in Poland, pp. 9-20. W. Szafer Institute of Botany, Polish Academy of Sciences, Kraków. 